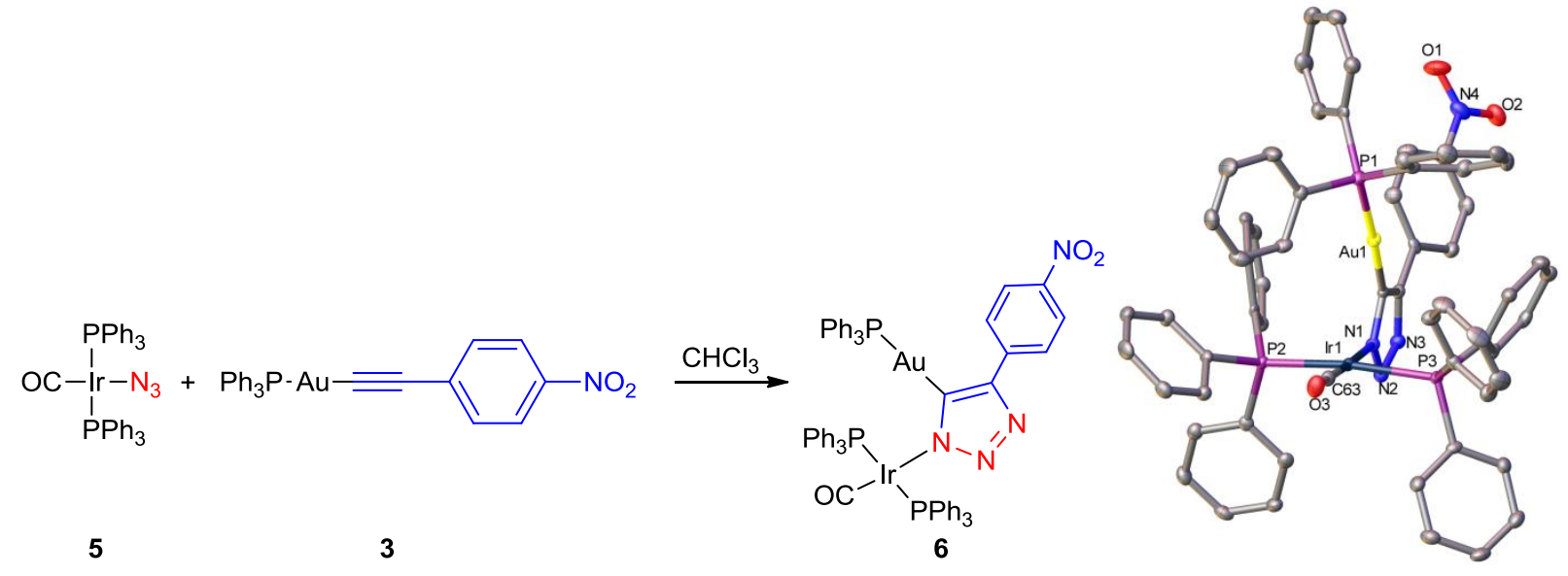


Gold-azides undergo cycloaddition (iClick) to group 9 azido complexes to give triazolate bridged heterobimetallic complexes. 


\title{
Expanding iClick to group 9 metals.
}

\author{
Christopher C. Beto, Xi Yang, Andrew R. Powers, Ion Ghiviriga, Khalil A. Abboud, and Adam \\ S. Veige* \\ University of Florida, Center for Catalysis, P.O. Box 117200, Gainesville, Florida, 32611. \\ Corresponding author: veige@chem.ufl.edu, University of Florida, Center for Catalysis, P.O. Box 117200, Gainesville, FL, \\ 32611. Tel.: 352-392-9844; fax: 352-392-3255.
}

\begin{abstract}
The iClick (inorganic click) reactions between gold-acetylides and group 9 transition metal-azide complexes are presented. Complexes $\left[\mathrm{Rh}(\mathrm{CO})\left(\mathrm{PPh}_{3}\right)_{2}\right]\left[\mathrm{PPh}_{3} \mathrm{Au}\right]\left(\mu-\mathrm{N}_{3} \mathrm{C}_{2} \mathrm{C}_{6} \mathrm{H}_{4} \mathrm{NO}_{2}\right) \quad$ (3), $\left\{\left[\mathrm{Rh}(\mathrm{CO})\left(\mathrm{PPh}_{3}\right)\right]\left[\mathrm{PPh}_{3} \mathrm{Au}\right]\left(\mu-\mathrm{N}_{3} \mathrm{C}_{2} \mathrm{C}_{6} \mathrm{H}_{4} \mathrm{NO}_{2}\right)\right\}_{2} \quad(\mathbf{4}), \quad$ and $\quad\left[(\mathrm{CO})\left(\mathrm{PPh}_{3}\right)_{2} \mathrm{IrAuPPh}_{3}\right](\mu-$ $\mathrm{N}_{3} \mathrm{C}_{2} \mathrm{C}_{6} \mathrm{H}_{4} \mathrm{NO}_{2}$ ) (6) have been synthesized via $\mathrm{M}$-azide/M-acetylide cycloaddition reactions between $\mathrm{PPh}_{3} \mathrm{Au}\left(\mathrm{C} \equiv \mathrm{CC}_{6} \mathrm{H}_{4} \mathrm{NO}_{2}\right)$ (2) and either $\mathrm{Rh}(\mathrm{CO})\left(\mathrm{PPh}_{3}\right)_{2} \mathrm{~N}_{3}(\mathbf{1})$, or $\operatorname{Ir}(\mathrm{CO})\left(\mathrm{PPh}_{3}\right)_{2} \mathrm{~N}_{3}$ (5). Complexes 3, 4, and 6 have been characterized by a combination of NMR spectroscopies, crystallography and combustion analysis.
\end{abstract}

\section{Keywords}

iClick; azide-alkyne cycloaddition; rhodium; iridium; gold; heterobimetallic; 


\section{Introduction}

Metallopolymers are on the cusp of revolutionizing the energy sector, information storage, and materials synthesis [1]. Transition metal chemistry marries polymer science in these hybrid materials wherein the metal ion imparts new properties unimaginable for organic polymers alone [2]. The challenge for synthetic chemists is to find new methods to covalently incorporate metal ions into polymer chains. Preparing metallopolymers requires either appending metal ions to an already existing polymer backbone or incorporating them into the repeating unit directly [3-32]. Conjugated platinum(II) acetylide oligomers/polymers, studied extensively by Schanze and coworkers [33-40], are hallmark examples of incorporating metal ions into the propagating repeat unit. The platinum ions engender photophysical properties that are challenging or impossible to replicate by organic polymers alone. New methods are necessary though to extend the synthetic versatility and control over metallopolymer composition, molecular weight, optical, and conductive properties.
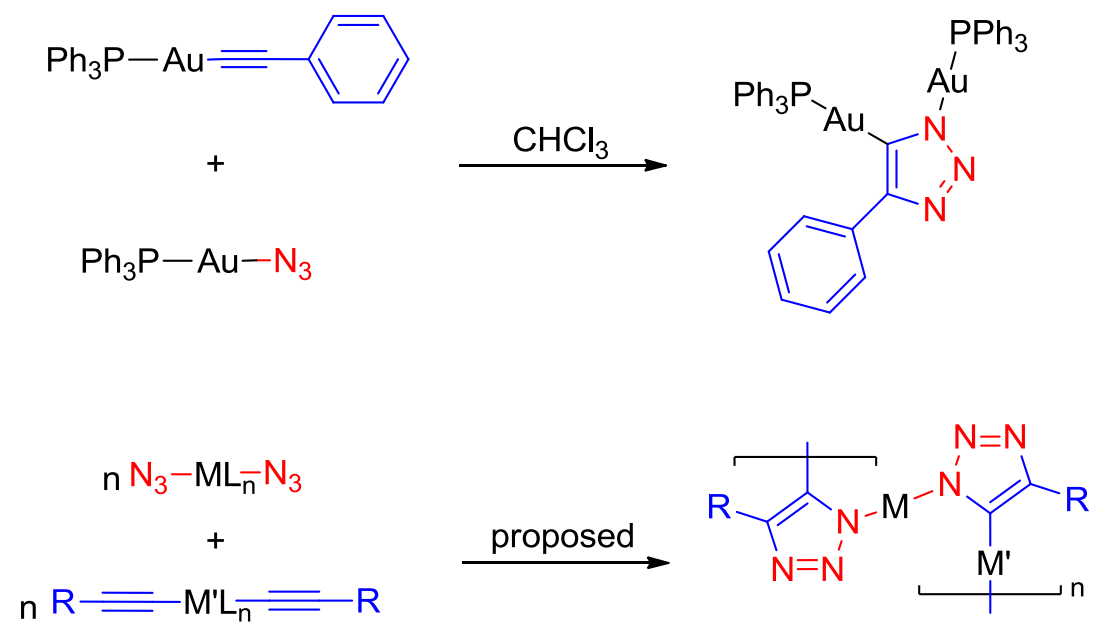

Figure 1. (a) Cycloaddition reaction between $\left(\mathrm{PPh}_{3}\right) \mathrm{AuC} \equiv \mathrm{CPh}$ and $\left(\mathrm{PPh}_{3}\right) \mathrm{AuN}_{3}$ to give a digold triazolate. (b) Proposed extension of the cycloaddition reaction to produce metallopolymers.

In 2010 [41], we published the cycloaddition reaction between a gold(I)-acetylide and a gold(I)-azide to from a triazolate linked digold complex (Figure 1a); and termed the reaction 
inorganic click (iClick) to acknowledge the two metal ions that substitute either protons or organic substituents in typical copper-catalyzed azide-alkyne cycloadditions (CuAAC) [42, 43]. Subsequently, we extended the reaction to include Pt(II) ions, and proposed methods to exploit the reaction to prepare metallopolymers (Figure 1b). Recently, by combining iClick with multiple aurophilic interactions, we prepared solution stable organogold oligomers [44]. Interrogating the mechanism [45] of reaction (a) reveals that the $\mathrm{Au}(\mathrm{I})$-acetylide is a necessary partner to a successful iClick reaction. Au(I)-acetylide is necessary because it plays the role of the in situ generated $\mathrm{Cu}(\mathrm{I})$-acetylide in prototypical $\mathrm{CuAAC}$ reactions [46]. Ongoing studies focus on alleviating the requirement for a $\mathrm{Au}(\mathrm{I})$-acetylide partner. In the meantime, to be a useful synthetic methodology and to ultimately apply iClick to the synthesis of metallopolymers, extension across the periodic table to new metal ions is necessary. In this manuscript we extend the iClick reaction to now include group 9 azido complexes.

\section{Results and Discussion}

\subsection{Synthesis and characterization of $\left[\mathrm{Rh}(\mathrm{CO})\left(\mathrm{PPh}_{3}\right)_{2}\right]\left[\mathrm{PPh}_{3} \mathrm{Au}\right]\left(\mu-\mathrm{N}_{3} \mathrm{C}_{2} \mathrm{C}_{6} \mathrm{H}_{4} \mathrm{NO}_{2}\right) \quad$ (3), $\left\{\left[R h(C O)\left(P P h_{3}\right)\right]\left[P P h_{3} A u\right]\left(\mu-N_{3} C_{2} C_{6} H_{4} N O_{2}\right)\right\}_{2}(4)$.}

To expand iClick to group 9 transition metals, the first reaction involved treating the gold(I)acetylide, $\mathrm{PPh}_{3} \mathrm{Au}\left(\mathrm{C} \equiv \mathrm{CC}_{6} \mathrm{H}_{4} \mathrm{NO}_{2}\right)$ (2) [47], with the rhodium-azide, $\mathrm{Rh}(\mathrm{CO})\left(\mathrm{PPh}_{3}\right)_{2} \mathrm{~N}_{3}$ (1) [4850] at ambient temperature in chloroform. Upon combining the reagents an instantaneous color change from orange to bright yellow occurs. Three products, the hetero-bimetallic complex, $\left[\mathrm{Rh}(\mathrm{CO})\left(\mathrm{PPh}_{3}\right)_{2}\right]\left[\mathrm{PPh}_{3} \mathrm{Au}\right]\left(\mu-\mathrm{N}_{3} \mathrm{C}_{2} \mathrm{C}_{6} \mathrm{H}_{4} \mathrm{NO}_{2}\right) \quad(3), \quad$ the hetero-tetranuclear complex, $\left\{\left[\mathrm{Rh}(\mathrm{CO})\left(\mathrm{PPh}_{3}\right)\right]\left[\mathrm{PPh}_{3} \mathrm{Au}\right]\left(\mu-\mathrm{N}_{3} \mathrm{C}_{2} \mathrm{C}_{6} \mathrm{H}_{4} \mathrm{NO}_{2}\right)\right\}_{2}(4)$, and free $\mathrm{PPh}_{3}$ form in solution after $20 \mathrm{~h}$. Complex $\mathbf{3}$ is the kinetic product (eq 1) and routinely forms with a variable amount of $\mathbf{4}$ present (eq 2). Providing further evidence for the mononer/dimer relationship, a ${ }^{1} \mathrm{H}$ DOSY NMR 
experiment performed on the mixture reveals two diffusion coefficients of $4.5 \times 10^{-10} \mathrm{~m}^{2} / \mathrm{s}$ and $3.6 \times 10^{-10} \mathrm{~m}^{2} / \mathrm{s}$ for 3 and 4 , respectively. The ratio between the two diffusion coefficients is 1.25, a result predicted for a monomer/dimer relationship [44, 51]. Varying the reaction temperature permits independent isolation of complexes 3 and 4 . Performing the reaction at $0{ }^{\circ} \mathrm{C}$ yields only monomer 3 , while heating at $55^{\circ} \mathrm{C}$ provides dimer 4 . In the procedure for isolating dimer $\mathbf{4}$, after initially heating the reaction mixture all volatiles were removed in vacuo and the resulting solid was washed with pentane to remove free $\mathrm{PPh}_{3}$; the cycle of heating and washing was repeated again to isolate pure 4.
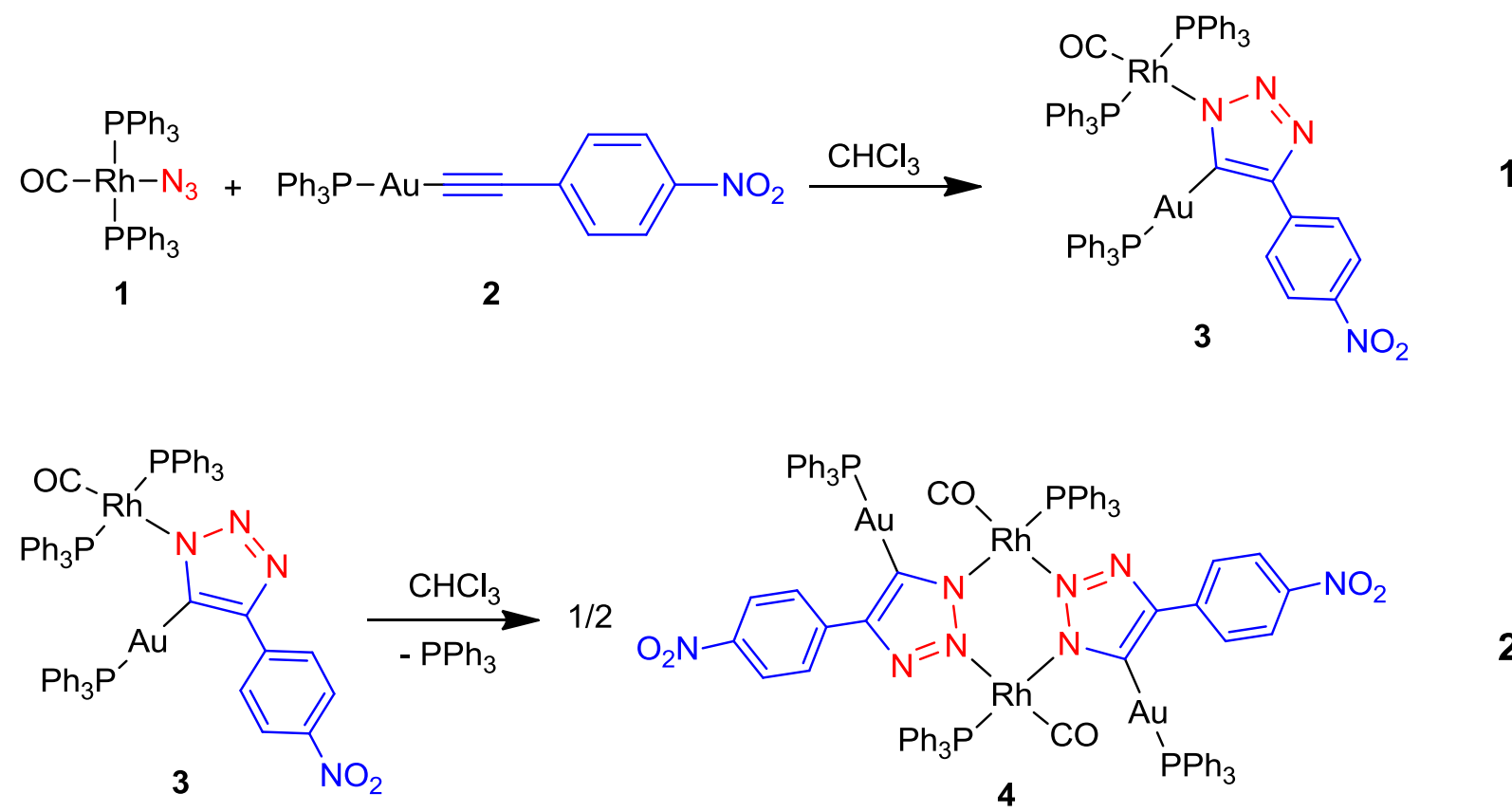

\section{2}

A variable temperature $\left(25-60{ }^{\circ} \mathrm{C}\right){ }^{1} \mathrm{H}$ NMR experiment performed on the mixture provided conclusive evidence that $\mathbf{3}$ and $\mathbf{4}$ are not in equilibrium. Heating the mixture from $25-60{ }^{\circ} \mathrm{C}$ altered the ratio of $\mathbf{3}$ and $\mathbf{4}$ from 1:0.5 to 1:1.1; however, cooling the mixture back to $25^{\circ} \mathrm{C}$ did not return the ratio to 1:0.5. Instead, 3 simply converted with time to produce more 4 . Repeated recrystallization of the mixture from dichloromethanelhexanes provides complex 4 in reasonable purity; The ${ }^{1} \mathrm{H}$ NMR and ${ }^{31} \mathrm{P}\left\{{ }^{1} \mathrm{H}\right\}$ spectra of recrystallized 4 indicate the complex is pure; 
however, combustion analyses gave a low value for the \% carbon, a result of incomplete combustion or the presence of an NMR silent impurity. For both complexes 3 and 4, combustion analysis results are consistent with the presence of $\mathrm{CH}_{2} \mathrm{Cl}_{2}$ in the solid. ${ }^{1} \mathrm{H}$ NMR spectrum of samples analysed via combustion analysis show the presence of one and two molecules of $\mathrm{CH}_{2} \mathrm{Cl}_{2}$ for $\mathbf{3}$, and 4 respectively.

In the ${ }^{31} \mathrm{P}\left\{{ }^{1} \mathrm{H}\right\}$ NMR spectrum, complex 4 exhibits a doublet resonance at $44.2 \mathrm{ppm}\left(J_{\mathrm{RhP}}=\right.$ $153 \mathrm{~Hz}$ ) and a singlet at $43.7 \mathrm{ppm}$ corresponding to the $\underline{\mathbf{P}} \mathrm{RhN}$ and $\underline{\mathbf{P}} \mathrm{AuC}$ phosphorus atoms, respectively. In the presence of free $\mathrm{PPh}_{3}$ the resonance centered at $43.65 \mathrm{ppm}$ in $\mathbf{4}$ broadens, indicating rapid exchange with the substitutional labile $\mathrm{PPh}_{3}$ on the $\mathrm{Au}(\mathrm{I})$ ion.

Crystals of complex 4 suitable for a single crystal X-ray interrogation grow via diffusion of hexanes into a dichloromethane solution of $\mathbf{4}$. The structure provides conclusive evidence for a hetero-tetranuclear complex. Complex 4 forms via loss of $\mathrm{PPh}_{3}$ from 3 and dimerization occurs through the triazolate $\mathrm{N}$-atom in the 2-position that binds to the vacated coordination site on the $\mathrm{Rh}(\mathrm{I})$ center. The triazolate orients with the $\mathrm{Au}(\mathrm{I})-\mathrm{PPh}_{3}$ units in anti-positions relative to each other; a result most likely due to sterics since the syn orientation would place both $\mathrm{Au}(\mathrm{I})-\mathrm{PPh}_{3}$ units in close proximity. As expected, the $\mathrm{Au}(\mathrm{I})$ ion and the $\mathrm{Rh}(\mathrm{I})$ ions adopt linear and square planar geometries, respectively. The two $\mathrm{Au}(\mathrm{I})$ ions have nearly linear bond angles that are statistically identical $(\mathrm{Au} 1=176.85(10)$ and Au2 $=176.82(11) \AA)$. Some distortion occurs in the square plane of the $\mathrm{Rh}(\mathrm{I})$ ions; most obvious are the small angles between the $\mathrm{N}$-atoms caused by the bridging triazolates $\left(\mathrm{N} 6-\mathrm{Rh} 1-\mathrm{N} 1=87.32(12)\right.$ and $\left.\mathrm{N} 2-\mathrm{Rh} 2-\mathrm{N} 5=86.69(11)^{\circ}\right)$. 


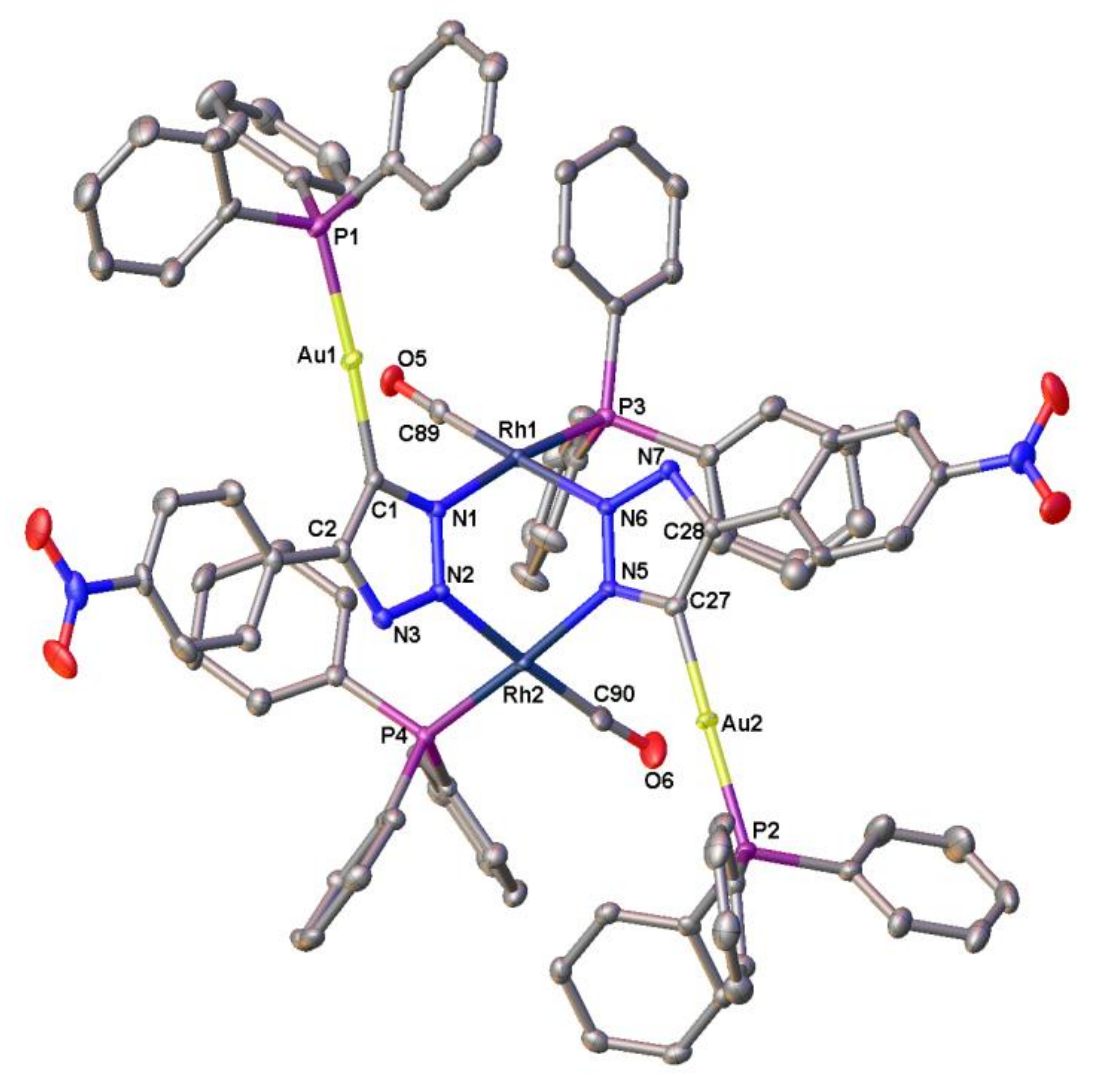

Figure 2. Solid state molecular structure of $\mathbf{4}$, with ellipsoids drawn at the $50 \%$ probability level with the major component of the disordered structure shown . The selected bond lengths $(\AA)$ and angles (deg): $\mathrm{Au}(1)-\mathrm{C}(1)$ 2.023(4), $\mathrm{Au}(2)-\mathrm{C}(27)$ 2.013(4), $\mathrm{Rh}(1)-\mathrm{N}(1)$ 2.101(3), $\mathrm{Rh}(1)-\mathrm{N}(6)$ 2.065(3), $\mathrm{Rh}(2)-\mathrm{N}(2)$ 2.073(3), $\mathrm{Rh}(2)-\mathrm{N}(5)$ 2.089(3), C(1)-Au(1)-P(1) 176.85(10), C(27)-Au(2)$\mathrm{P}(2)$ 176.82(11), C(89)-Rh(1)-N(6) 178.34(14), N(1)-Rh(1)-P(3) 172.93(8), C(90)-Rh(2)-N(2) 176.93(14), N(5)-Rh(2)-P(4) 176.75(9), N6-Rh1-N1 = 87.32(12) and N2-Rh2-N5 = 86.69(11) ${ }^{\circ}$.

Complex $\mathbf{3}$ was characterized via multinuclear-NMR (see ESI). Of note, in the ${ }^{31} \mathrm{P}\left\{{ }^{1} \mathrm{H}\right\}$ NMR spectrum of $\mathbf{3}$, a doublet resonance $\left(J_{\mathrm{RhP}}=137 \mathrm{~Hz}\right)$ at $29.7 \mathrm{ppm}$ and a singlet resonance at 43.7 ppm are attributable to the $\underline{\mathbf{P}} \mathrm{RN}$ and $\underline{\mathbf{P}} \mathrm{AuC}$ phosphorus atoms, respectively. 3.2 Synthesis and characterization of $\left[(\mathrm{CO})\left(\mathrm{PPh}_{3}\right)_{2} \mathrm{Ir}-\mathrm{AuPPh} \mathrm{h}_{3}\right]\left(\mu-\mathrm{N}_{3} \mathrm{C}_{2} \mathrm{C}_{6} \mathrm{H}_{4} \mathrm{NO}_{2}\right)(\mathbf{6})$. 
Similar to $\mathrm{Rh}(\mathrm{I})$, the third row group 9 transition metal, $\operatorname{Ir}(\mathrm{I})$, also participates in iClick reactions. Treating the azide derivative of Vaska's complex $\mathbf{5}$ with $\mathbf{3}$ in chloroform at room temperature results in an instantaneous color change from orange to dark red and provides the hetero-bimetallic complex 6 in $28 \%$ yield (isolated). The ${ }^{31} \mathrm{P}\left\{{ }^{1} \mathrm{H}\right\}$ NMR spectrum of 6 exhibits two singlet resonances at $43.4 \mathrm{ppm}$ and $23.2 \mathrm{ppm}$ corresponding to the $\underline{\mathbf{P A u C}}$ and $\underline{\mathbf{P} I r N}$ phosphorus atoms, respectively. A variable temperature ${ }^{31} \mathrm{P}\left\{{ }^{1} \mathrm{H}\right\}$ NMR study of 6 indicates that, from $-60{ }^{\circ} \mathrm{C}$ to $50{ }^{\circ} \mathrm{C}$, the resonances do not change. The variable temperature data indicate that a monomer/dimer equilibrium or reaction does not occur for complex $\mathbf{6}$. 


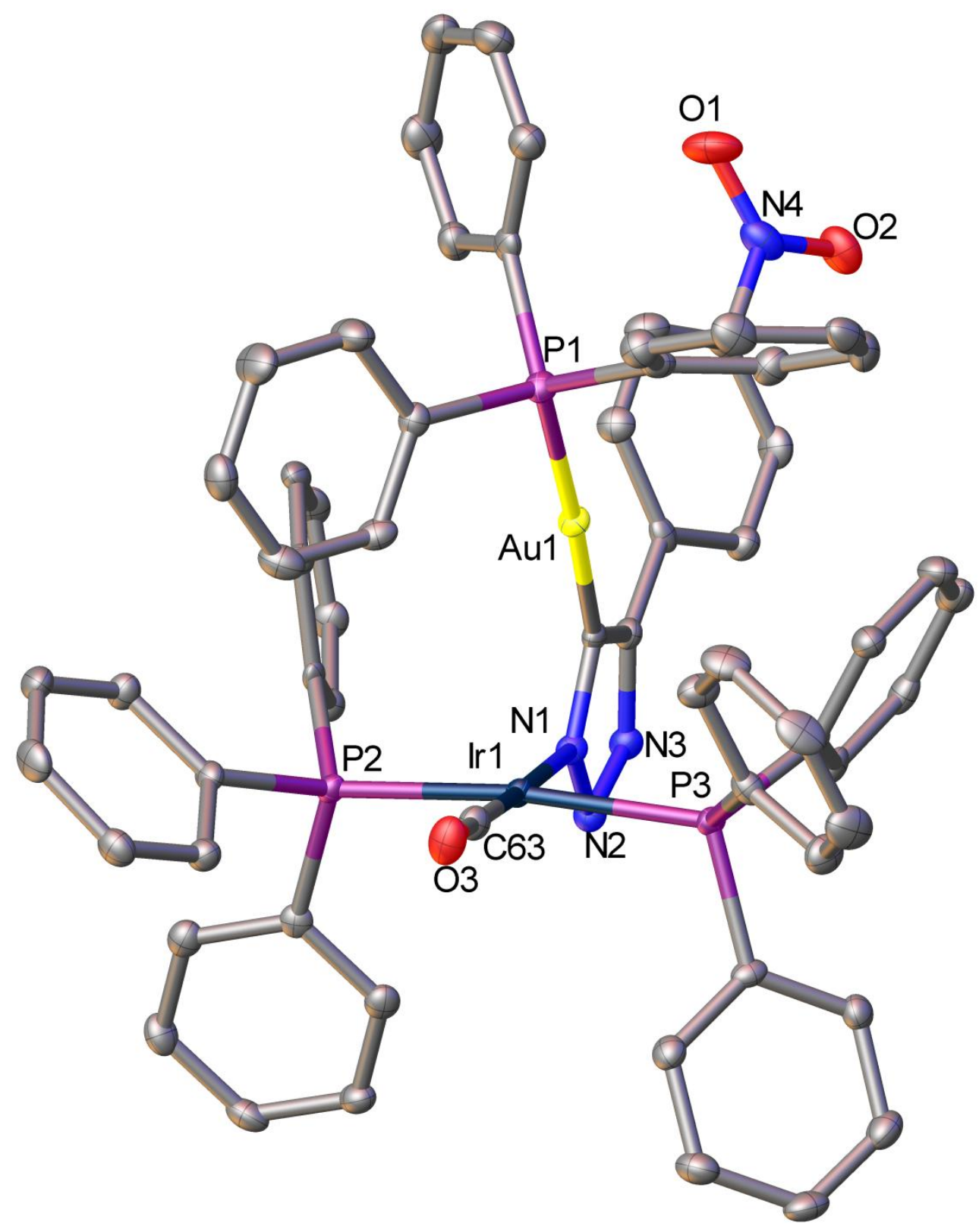

Figure 3. The solid state molecular structure of complex 6 (All solvent molecules and $\mathrm{H}$ atoms are removed for clarity).

Crystals of $\mathbf{6}$ interrogated by X-ray crystallography provide conclusive evidence for its identity in the solid state. Complex 6 exhibits an unusual orientation of the $\mathrm{Au}(\mathrm{I})$ ion. In previous structures obtained via iClick the gold ions orient in positions that alleviate steric congestion and point away from the adjacent metal ion [52]. In complex 6 though, the Au(I) ion sits directly 
over the $\operatorname{Ir}(\mathrm{I})$ ion suggesting a $\operatorname{Ir}-\mathrm{Au}$ interaction. However, it is clear no bond exists since the atoms are separated by 3.2770 (3) $\AA$, a distance that is well-outside the range reported for Ir- $\mathrm{Au}$ bonds of $2.59 \AA-2.81 \AA[53-62]$.

\section{Conclusions}

The reaction between $\mathrm{Au}(\mathrm{I})$-acetylide and group 9 azide complexes results in the [3+2] azide/acetylide cycloaddition to give (initially for Rh) hetero-dimetallic complexes bridged by a triazolate. In the case of $\mathrm{Rh}(\mathrm{I})$ the reaction proceeds to eventually form a tetranuclear complex via dimerization, whereas for $\operatorname{Ir}(\mathrm{I})$ the reaction stops at the monomer. Even heating complex $\mathbf{6}$ at $50{ }^{\circ} \mathrm{C}$ does not promote dimerization. An explanation is that the $\mathrm{Ir}-\mathrm{PPh}_{3}$ bond must be favoured over the Ir-N bond that would form in the dimerization. The entropic driving force should be favourable since the dimerization leads to loss of $\mathrm{PPh}_{3}$. As mentioned in the introduction, it is now clear that the $\mathrm{Au}(\mathrm{I})$-acetylide plays the same role as $\mathrm{Cu}(\mathrm{I})$-acetylide in $\mathrm{CuAAC}$ [45], thus no M-azide/M-acetylide reactions have worked so far when M-acetylide is a metal other than $\mathrm{Au}(\mathrm{I})$; overcoming this challenge is ongoing work in our laboratories.

\section{Experimental}

\subsection{Materials and Methods}

Unless specified otherwise, all manipulations were performed under an inert atmosphere using standard Schlenk or glove-box techniques. Hexanes, methylene chloride, tetrahydrofuran and toluene were degassed by sparging with high purity argon, and were dried using a GlassContour drying column. Methanol was dried over anhydrous copper(II)sulfate, distilled and stored over 4 $\AA$ molecular sieves; chloroform-d (Cambridge Isotopes) was dried over copper(II) sulfate/calcium chloride, distilled, and stored over $4 \AA$ molecular sieves. ${ }^{1} \mathrm{H}$ and ${ }^{13} \mathrm{C}$ NMR spectra were obtained on Varian INOVA spectrometer, operating at $500 \mathrm{MHz}$ for proton. The 
${ }^{31} \mathrm{P}\left\{{ }^{1} \mathrm{H}\right\}$ spectra were obtained on a Varian Mercury spectrometer, operating at $300 \mathrm{MHz}$ for proton. Chemical shifts, reported in $\delta(\mathrm{ppm})$, were referenced on the solvent, on the TMS scale for ${ }^{1} \mathrm{H}$ and ${ }^{13} \mathrm{C}$ and on the $\mathrm{H}_{3} \mathrm{PO}_{4}$ scale for ${ }^{31} \mathrm{P}$.

Elemental analyses were performed at Complete Analysis Laboratory Inc., Parsippany, New Jersey. The following materials were purchased and used as received: $\operatorname{Ir}(\mathrm{CO})\left(\mathrm{PPh}_{3}\right)_{2} \mathrm{Cl}(\mathrm{Strem})$, $\mathrm{Rh}(\mathrm{CO})\left(\mathrm{PPh}_{3}\right)_{2} \mathrm{Cl}$ (Sigma-Aldrich). The following compounds were synthesized by literature methods: $\mathrm{Rh}(\mathrm{CO})\left(\mathrm{PPh}_{3}\right)_{2} \mathrm{~N}_{3}(\mathbf{1})$ [48-50], $\mathrm{Ir}(\mathrm{CO})\left(\mathrm{PPh}_{3}\right) \mathrm{N}_{3}(\mathbf{2})$ [48-50], $\mathrm{PPh}_{3} \mathrm{Au}\left(\mathrm{C} \equiv \mathrm{CC}_{6} \mathrm{H}_{4} \mathrm{NO}_{2}\right)$ (3) [47].

\subsubsection{Synthesis of $\left[R h(C O)\left(P P h_{3}\right)_{2}\right]\left[P P h_{3} A u\right]\left(\mu-N_{3} C_{2} C_{6} H_{4} N_{2}\right)(3)$.}

In a vial, $1(35.0 \mathrm{mg}, 0.0578 \mathrm{mmol})$ and $2(40.3 \mathrm{mg}$, $0.0578 \mathrm{mmol}$ ) were dissolved in $2 \mathrm{ml}$ of $\mathrm{CHCl}_{3}$ and kept at 0 ${ }^{\circ} \mathrm{C}$ for $10 \mathrm{~h}$. The solvent was removed in vacuo and the residue was recrystallized from $\mathrm{CH}_{2} \mathrm{Cl}_{2}$ and hexanes at -25 ${ }^{\circ} \mathrm{C}$ to provide 3 as yellow crystals $(78.4 \mathrm{mg}, 83.9 \%) .{ }^{1} \mathrm{H}$ $\operatorname{NMR}\left(500 \mathrm{MHz}, \mathrm{CDCl}_{3,25}{ }^{\circ} \mathrm{C}, \delta(\mathrm{ppm})\right): 8.01\left(\mathrm{~d},{ }^{3} \mathrm{~J}_{\mathrm{HH}}=9.1\right.$ $\left.\mathrm{Hz}, 2 \mathrm{H}, H \mathrm{C}_{4}\right), 7.96\left(\mathrm{~d},{ }^{3} J_{\mathrm{HH}}=8.9 \mathrm{~Hz}, 2 \mathrm{H}, H \mathrm{C}_{5}\right), 7.65(\mathrm{dd}$, $\left.{ }^{3} J_{\mathrm{HH}}=8.0 \mathrm{~Hz},{ }^{3} J_{\mathrm{PH}}=12.0 \mathrm{~Hz}, 6 \mathrm{H}, H \mathrm{C}_{8}\right), 7.59\left(\mathrm{~m}, 3 \mathrm{H}, H \mathrm{C}_{4}\right)$,

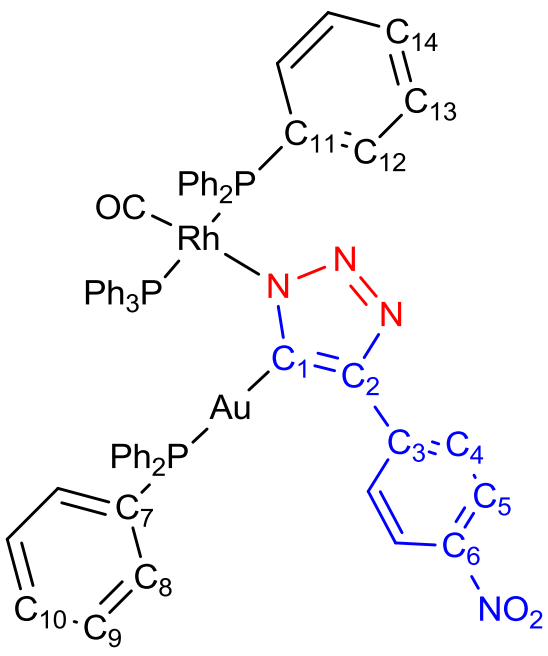
$7.49\left(\mathrm{~m}, 18 \mathrm{H}, H_{9}, H \mathrm{C}_{12}\right), 7.24\left(\mathrm{t},{ }^{3} J_{\mathrm{HH}}=7.6 \mathrm{~Hz}, 6 \mathrm{H}, H \mathrm{C}_{14}\right), 7.11\left(\mathrm{t},{ }^{3} J_{\mathrm{HH}}=7.5 \mathrm{~Hz}, 12 \mathrm{H}, H \mathrm{C}_{13}\right)$. ${ }^{13} \mathrm{C}\left\{{ }^{1} \mathrm{H}\right\}$ NMR Shifts $\left(500 \mathrm{MHz}, \mathrm{CDCl}_{3}, 25{ }^{\circ} \mathrm{C}, \delta(\mathrm{ppm})\right): 151.3\left(\mathrm{C}_{2}\right), 144.4\left(\mathrm{C}_{3}\right), 144.2\left(\mathrm{C}_{6}\right)$, 134.4 $\left(\mathrm{C}_{8}\right), 134.3\left(\mathrm{C}_{12}\right), 132.3\left(\mathrm{C}_{11}\right), 131.6\left(\mathrm{C}_{10}\right), 130.9\left(\mathrm{C}_{7}\right), 129.8\left(\mathrm{C}_{14}\right), 129.2\left(\mathrm{C}_{9}\right), 128.0\left(\mathrm{C}_{13}\right)$, $124.8\left(\mathrm{C}_{4}\right), 123.4\left(\mathrm{C}_{5}\right) .{ }^{31} \mathrm{P}\left\{{ }^{1} \mathrm{H}\right\} \mathrm{NMR}\left(121.4 \mathrm{MHz}, \mathrm{CDCl}_{3}, 25{ }^{\circ} \mathrm{C}, \delta(\mathrm{ppm})\right): 43.70(\mathrm{~s}, \underline{\mathbf{P}} \mathrm{AuC})$, $29.70\left(\mathrm{~d}, J_{\mathrm{RhP}}=137 \mathrm{~Hz}, \underline{\mathbf{P R h N}}\right)$. Anal. Calcd. $(\%)$ for $\mathrm{C}_{64} \mathrm{H}_{51} \mathrm{AuCl}_{2} \mathrm{~N}_{4} \mathrm{O}_{3} \mathrm{P}_{3} \mathrm{Rh}(\mathrm{Complex} 3$ with one molecule of methylene chloride, confirmed by ${ }^{1} \mathrm{H}$ NMR): C, 55.39; H, 3.70; N, 4.04. Found: 
C, 55.20; H, 3.46; N, 4.27.

4.2.2 Synthesis of $\left\{\left[\mathrm{Rh}(\mathrm{CO})\left(\mathrm{PPh}_{3}\right)\right]\left[\mathrm{PPh}_{3} \mathrm{Au}\right]\left(\mu-\mathrm{N}_{3} \mathrm{C}_{2} \mathrm{C}_{6} \mathrm{H}_{4} \mathrm{NO}_{2}\right)\right\}_{2}(4)$.

Complex 4 was synthesized in the same procedure as $\mathbf{3}$, with the exception that the reaction was heated to $50{ }^{\circ} \mathrm{C}$ for $30 \mathrm{~min}$, all volatiles removed and the resulting solid washed with hexanes to remove excess phosphine. The heating and washing was repeated again followed by

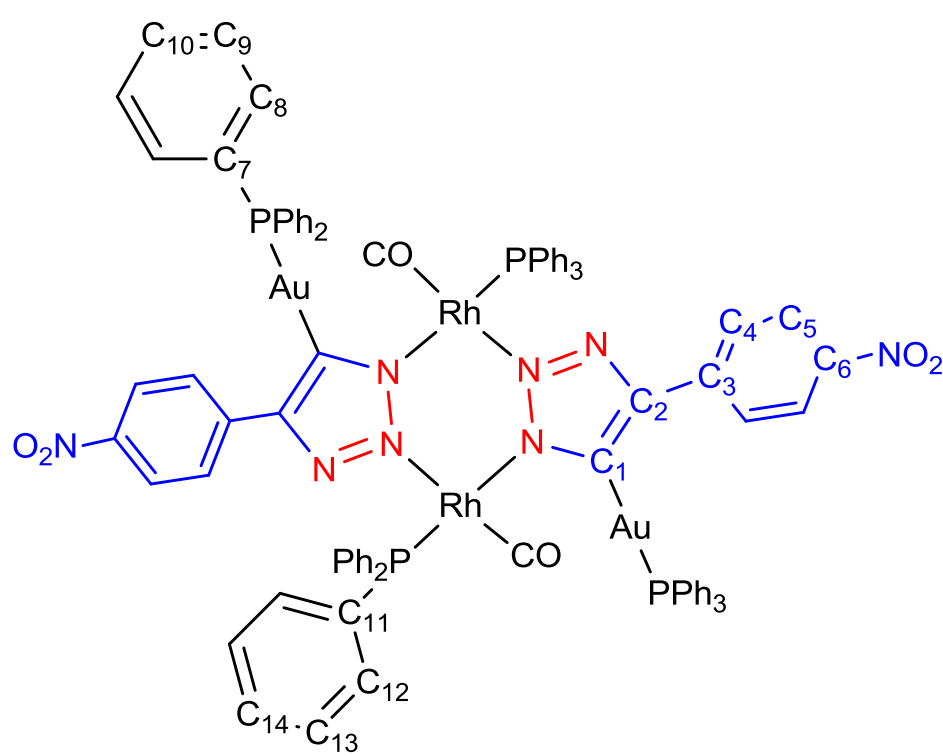
crystallization of complex $\mathbf{4}$ at room temperature from dichloromethanelhexanes. Complex $\mathbf{4}$ was isolated as yellow crystals. ${ }^{1} \mathrm{H}$ NMR $\left(500 \mathrm{MHz}, \mathrm{CDCl}_{3}, 25{ }^{\circ} \mathrm{C}, \delta(\mathrm{ppm})\right): 7.97\left(\mathrm{~d},{ }^{3} J_{\mathrm{HH}}=9.0 \mathrm{~Hz}\right.$, $\left.4 \mathrm{H}, H \mathrm{C}_{4}\right), 7.92\left(\mathrm{~d},{ }^{3} J_{\mathrm{HH}}=9.3 \mathrm{~Hz}, 4 \mathrm{H}, H \mathrm{C}_{5}\right), 7.75\left(\mathrm{dd},{ }^{3} J_{\mathrm{HH}}=8.0 \mathrm{~Hz},{ }^{3} J_{\mathrm{PH}}=11.1 \mathrm{~Hz}, 12 \mathrm{H}, H \mathrm{C} 8\right)$, $7.31\left(\mathrm{~m}, 6 \mathrm{H}, H \mathrm{C}_{10}\right), 7.21\left(\mathrm{~m}, 12 \mathrm{H}, H \mathrm{C}_{9}\right) .{ }^{13} \mathrm{C}\left\{{ }^{1} \mathrm{H}\right\}$ NMR Shifts $\left(500 \mathrm{MHz}, \mathrm{CDCl}_{3}, 25{ }^{\circ} \mathrm{C}, \delta\right.$ $(\mathrm{ppm})): 154.1\left(\mathrm{C}_{2}\right), 144.9\left(\mathrm{C}_{6}\right), 142.9\left(\mathrm{C}_{3}\right), 134.5\left(\mathrm{C}_{8}\right), 134.0\left(\mathrm{C}_{7}\right), 129.6\left(\mathrm{C}_{10}\right), 127.8\left(\mathrm{C}_{9}\right), 125.2$ $\left(\mathrm{C}_{4}\right), 123.2\left(\mathrm{C}_{5}\right) .{ }^{31} \mathrm{P}\left\{{ }^{1} \mathrm{H}\right\}$ NMR $\left(121.4 \mathrm{MHz}, \mathrm{CDCl}_{3}, 25{ }^{\circ} \mathrm{C}, \delta(\mathrm{ppm})\right): 44.2\left(\mathrm{~d}, J_{\mathrm{RhP}}=152 \mathrm{~Hz}\right.$, PRhN), 43.7 (s, $\underline{\mathbf{P} A u C}$ ). Anal. Calcd. (\%) for $\mathrm{C}_{92} \mathrm{H}_{72} \mathrm{Cl}_{4} \mathrm{Au}_{2} \mathrm{~N}_{8} \mathrm{O}_{6} \mathrm{P}_{4} \mathrm{Rh}_{2}$ (Complex 4 with two molecules of methylene chloride, confirmed by ${ }^{1} \mathrm{H}$ NMR): C, 49.09; H, 3.22; N, 4.98. Found: C, 48.98; H, 3.19; N, 4.73 .

4.2.3 Synthesis of $\left[(\mathrm{CO})\left(\mathrm{PPh}_{3}\right)_{2} \mathrm{Ir}-\mathrm{AuPPh} \mathrm{h}_{3}\right]\left(\mu-\mathrm{N}_{3} \mathrm{C}_{2} \mathrm{C}_{6} \mathrm{H}_{4} \mathrm{NO}_{2}\right)(\boldsymbol{6})$.

In a vial, $5(18.2 \mathrm{mg}, 0.0231 \mathrm{mmol})$ and $\mathbf{3}(14.0 \mathrm{mg}, 0.0231 \mathrm{mmol})$ were dissolved in $2 \mathrm{ml}$ of $\mathrm{CHCl}_{3}$ and then stirred for $20 \mathrm{~h}$. The solvent was removed in vacuo and the residue was recrystallized from $\mathrm{CH}_{2} \mathrm{Cl}_{2}$ and hexanes to provide pure 6 as yellow crystals $(8.8 \mathrm{mg}, 28 \%) .{ }^{1} \mathrm{H}$ 
$\operatorname{NMR}\left(500 \mathrm{MHz}, \mathrm{CDCl}_{3}, 25{ }^{\circ} \mathrm{C}, \delta(\mathrm{ppm})\right): 8.00\left(\mathrm{~d},{ }^{3} J_{\mathrm{HH}}=8.5 \mathrm{~Hz}, 2 \mathrm{H}, H \mathrm{C}_{4}\right), 7.96\left(\mathrm{~d},{ }^{3} J_{\mathrm{HH}}=8.5\right.$ $\left.\mathrm{Hz}, 2 \mathrm{H}, H \mathrm{C}_{5}\right), 7.67\left(\mathrm{dd},{ }^{3} J_{\mathrm{PH}}=11.1 \mathrm{~Hz},{ }^{3} J_{\mathrm{HH}}=8.1 \mathrm{~Hz}, 6 \mathrm{H}, H \mathrm{C}_{8}\right), 7.58\left(\mathrm{t},{ }^{3} J_{\mathrm{HH}}=7.2 \mathrm{~Hz}, 3 \mathrm{H}\right.$, $\left.H \mathrm{C}_{10}\right), 7.52\left(\mathrm{dd},{ }^{3} J_{\mathrm{PH}}=6.5 \mathrm{~Hz},{ }^{3} J_{\mathrm{HH}}=6.5 \mathrm{~Hz}, 6 \mathrm{H}, H \mathrm{C}_{12}\right), 7.50\left(\mathrm{t},{ }^{3} J_{\mathrm{HH}}=7.6 \mathrm{~Hz}, 6 \mathrm{H}, H \mathrm{C}_{9}\right), 7.23$ $\left(\mathrm{t},{ }^{3} J_{\mathrm{HH}}=7.2 \mathrm{~Hz}, 3 \mathrm{H}, H \mathrm{C}_{14}\right), 7.10\left(\mathrm{t},{ }^{3} J_{\mathrm{HH}}=7.2 \mathrm{~Hz}, 6 \mathrm{H}, H \mathrm{C}_{13}\right) .{ }^{13} \mathrm{C}\left\{{ }^{1} \mathrm{H}\right\} \mathrm{NMR}$ Shifts $(500 \mathrm{MHz}$, $\left.\mathrm{CDCl}_{3}, 25{ }^{\circ} \mathrm{C}, \delta(\mathrm{ppm})\right): 150.0\left(\mathrm{C}_{2}\right), 144.3\left(\mathrm{C}_{6}\right), 144.1\left(\mathrm{C}_{3}\right)$, 134.5( $\left.\mathrm{C}_{12}\right), \quad 134.4\left(\mathrm{C}_{8}\right), \quad 131.7\left(\mathrm{C}_{11}\right), \quad 131.6\left(\mathrm{C}_{10}\right), \quad 130.9\left(\mathrm{C}_{7}\right)$, 130.0 $\left(\mathrm{C}_{14}\right), \quad 129.2\left(\mathrm{C}_{9}\right), \quad 127.9\left(\mathrm{C}_{13}\right), \quad 124.8\left(\mathrm{C}_{4}\right), \quad 123.4\left(\mathrm{C}_{5}\right)$. ${ }^{31} \mathrm{P}\left\{{ }^{1} \mathrm{H}\right\}$ NMR (121.4 MHz, $\left.\mathrm{CDCl}_{3}, 25{ }^{\circ} \mathrm{C}, \delta(\mathrm{ppm})\right) \delta(\mathrm{ppm})$ :

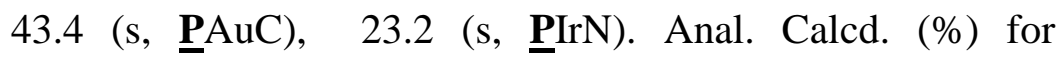
$\mathrm{C}_{63} \mathrm{H}_{49} \mathrm{AuIrN} \mathrm{Ir}_{4} \mathrm{O}_{3} \mathrm{P}_{3}: \mathrm{C}, 54.35 ; \mathrm{H}, 3.55 ; \mathrm{N}, 4.02$. Found: 1st sample, C, 54.04; H, 3.49; N, 4.14; Found: $2^{\text {nd }}$ sample C,

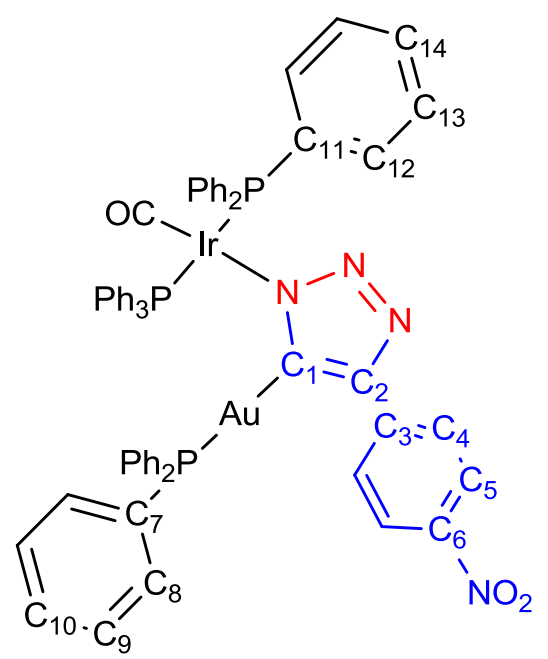
54.51; H, 3.72; N, 4.21.

\subsection{X-ray crystallography experimental details for 4 and $\mathbf{6}$.}

X-Ray Intensity data were collected at $100 \mathrm{~K}$ on a Bruker DUO diffractometer using MoK $\alpha$ radiation $(\lambda=0.71073 \AA)$ and an APEXII CCD area detector. Raw data frames were read by program SAINT[63] and integrated using 3D profiling algorithms. The data were corrected for Lorentz and polarization effects and numerical absorption corrections were applied based on indexed and measured faces. The structure was solved and refined in SHELXTL2013 [63], using full-matrix least-squares refinement. The non-H atoms were refined with anisotropic thermal parameters and all of the $\mathrm{H}$ atoms were calculated in idealized positions and refined riding on their parent atoms. Solid state structure drawings were created using the OLEX software package [64]. The refinement was carried out by minimizing the $\mathrm{wR}_{2}$ function using $\mathrm{F}^{2}$ 
rather than $F$ values. $R_{1}$ is calculated to provide a reference to the conventional $R$ value but its function is not minimized.

4: The asymmetric unit contains one complex, with the disorder modeled for three phenyl atoms C68, C69, and C70, of the triphenylphosphine ligand attached to Rh1, while the other three carbons of the ring, C65, C66 and C67, do not seem to be disordered for being at the libration axis C65-C67 causing the disorder. In the final cycle of refinement, 18662 reflections (of which 14647 are observed with $\mathrm{I}>2 \sigma(\mathrm{I})$ ) were used to refine 1007 parameters and the resulting $\mathrm{R}_{1}$, $\mathrm{wR}_{2}$ and $\mathrm{S}$ (goodness of fit) were $2.65 \%, 5.07 \%$ and 0.978 , respectively. The disorder was refined to $64: 36$ for the disordered components of the complex.

6: The asymmetric unit consists of the Au-Ir complex and two dichloromethane (DCM) solvent molecules. One DCM molecule is disordered and was refined in three parts with their site occupation factors restrained to unity. A look at the FoFc table in the listing output file from the final refinement shows consistently higher values for Fo compared to their respective Fc values suggesting twinning. But the refinement, and the low values of Su's, also suggests that even if there was another crystal domain, it must be very insignificant. In the final cycle of refinement, 13547 reflections (of which 10771 are observed with $\mathrm{I}>2 \sigma(\mathrm{I})$ ) were used to refine 736 parameters and the resulting $\mathrm{R}_{1}, \mathrm{wR}_{2}$ and $\mathrm{S}$ (goodness of fit) were $2.66 \%, 5.30 \%$ and 0.988 , respectively.

\section{Acknowledgements}

Research supported by the U.S. Department of Energy, Office of Basic Energy Sciences, Division of Materials Sciences and Engineering under Award DE-SC0010510. KAA thanks UF and the NSF for funds to purchase X-ray equipment (CHE-0821346). 


\section{References}

[1] G. R. Whittell, I. Manners, Adv. Mater. 19 (2007) 3439-3468.

[2] G. R. Whittell, M. D. Hager, U. S. Schubert, I. Manners, Nat Mater 10 (2011) 176-188.

[3] S. J. Higgins, C. L. Jones, S. M. Francis, Synth. Met. 98 (1999) 211-214.

[4] Y. Zhu, M. O. Wolf, Chem. Mat. 11 (1999) 2995-3001.

[5] C. G. Cameron, P. G. Pickup, Chem. Commun. (1997) 303-304.

[6] M. Kurashina, M. Murata, T. Watanabe, H. Nishihara, J. Am. Chem. Soc. 125 (2003) 1242012421.

[7] H. Nishihara, M. Kurashina, M. Murata, Macromol. Symp. 196 (2003) 27-38.

[8] I. Tomita, A. Nishio, T. Igarashi, T. Endo, Polym. Bull. 30 (1993) 179-186.

[9] R. P. Kingsborough, T. M. Swager, J. Am. Chem. Soc. 121 (1999) 8825-8834.

[10] R. P. Kingsborough, T. M. Swager, Adv. Mater. 10 (1998) 1100-1104.

[11] D. H. Kim, J.-H. Kim, T. H. Kim, D. M. Kang, Y. H. Kim, Y.-B. Shim, S. C. Shin, Chem. Mat. 15 (2003) 825-827.

[12] D. H. Kim, D.-S. Park, Y.-B. Shim, S. C. Shin, J. Organomet. Chem. 608 (2000) 133-138.

[13] B. S. Kang, D. H. Kim, T. S. Jung, E. K. Jang, Y. Pak, S. C. Shin, D.-S. Park, Y.-B. Shim, Synth. Met. 105 (1999) 9-12.

[14] D. Hyun Kim, B. Soo Kang, S. Min Lim, K.-M. Bark, B. Gon Kim, M. Shiro, Y.-B. Shim, S. Chul Shin, J. Chem. Soc., Dalton Trans. (1998) 1893-1898.

[15] B. Jousselme, P. Blanchard, M. Ocafrain, M. Allain, E. Levillain, J. Roncali, J. Mater. Chem. 14 (2004) 421-427.

[16] R. Back, R. B. Lennox, Langmuir 8 (1992) 959-964.

[17] G. Zotti, S. Zecchin, G. Schiavon, A. Berlin, G. Pagani, A. Canavesi, Chem. Mat. 7 (1995) 23092315.

[18] G. Zotti, G. Schiavon, S. Zecchin, A. Berlin, G. Pagani, A. Canavesi, Synth. Met. 76 (1996) 255258.

[19] G. Zotti, G. Schiavon, S. Zecchin, A. Berlin, A. Canavesi, G. Pagani, Synth. Met. 84 (1997) 239240.

[20] H. Brisset, A.-E. Navarro, C. Moustrou, I. F. Perepichka, J. Roncali, Electrochem. Commun. 6 (2004) 249-253.

[21] J. L. Reddinger, J. R. Reynolds, Chem. Mat. 10 (1998) 3-5.

[22] J. Hjelm, R. W. Handel, A. Hagfeldt, E. C. Constable, C. E. Housecroft, R. J. Forster, Electrochem. Commun. 6 (2004) 193-200.

[23] J. Hjelm, R. W. Handel, A. Hagfeldt, E. C. Constable, C. E. Housecroft, R. J. Forster, J. Phys. Chem. B 107 (2003) 10431-10439.

[24] J. Hjelm, E. C. Constable, E. Figgemeier, A. Hagfeldt, R. Handel, C. E. Housecroft, E. Mukhtar, E. Schofield, Chem. Commun. (2002) 284-285.

[25] Y. Zhu, M. O. Wolf, J. Am. Chem. Soc. 122 (2000) 10121-10125.

[26] Z. Wang, A. R. McWilliams, C. E. B. Evans, X. Lu, S. Chung, M. A. Winnik, I. Manners, Adv. Funct. Mater. 12 (2002) 415-419.

[27] M. Groenewolt, T. Brezesinski, H. Schlaad, M. Antonietti, P. W. Groh, B. Iván, Adv. Mater. 17 (2005) 1158-1162.

[28] R. Resendes, A. Berenbaum, G. Stojevic, F. Jäkle, A. Bartole, F. Zamanian, G. Dubois, C. Hersom, K. Balmain, I. Manners, Adv. Mater. 12 (2000) 327-330.

[29] G. Wilbert, R. Zentel, Macromol. Chem. Phys. 197 (1996) 3259-3268.

[30] M. E. Wright, E. G. Toplikar, R. F. Kubin, M. D. Seltzer, Macromolecules 25 (1992) 1838-1839.

[31] H. Nishihara, T. Hirao, K. Aramaki, K. Aoki, Synth. Met. 84 (1997) 935-936.

[32] R. J. P. Corriu, N. Devylder, C. Guerin, B. Henner, A. Jean, J. Organomet. Chem. 509 (1996) 249257.

[33] T. Cardolaccia, A. M. Funston, M. E. Kose, J. M. Keller, J. R. Miller, K. S. Schanze, J. Phys. Chem. B 111 (2007) 10871-10880.

[34] L. de Quadras, A. H. Shelton, H. Kuhn, F. Hampel, K. S. Schanze, J. A. Gladysz, Organometallics 
[35] R. T. Farley, Q. Zheng, J. A. Gladysz, K. S. Schanze, Inorg. Chem. 47 (2007) 2955-2963.

[36] J. M. Keller, K. S. Schanze, Organometallics 28 (2009) 4210-4216.

[37] K.-Y. Kim, A. H. Shelton, M. Drobizhev, N. Makarov, A. Rebane, K. S. Schanze, J. Phys. Chem. A 114 (2010) 7003-7013.

[38] J. Mei, K. Ogawa, Y.-G. Kim, N. C. Heston, D. J. Arenas, Z. Nasrollahi, T. D. McCarley, D. B. Tanner, J. R. Reynolds, K. S. Schanze, ACS Appl. Mater. Interfaces 1 (2009) 150-161.

[39] P. Taranekar, Q. Qiao, H. Jiang, I. Ghiviriga, K. S. Schanze, J. R. Reynolds, J. Am. Chem. Soc. 129 (2007) 8958-8959.

[40] X. Zhao, T. Cardolaccia, R. T. Farley, K. A. Abboud, K. S. Schanze, Inorg. Chem. 44 (2005) 26192627.

[41] T. J. Del Castillo, S. Sarkar, K. A. Abboud, A. S. Veige, Dalton Trans. 40 (2011) 8140-8144.

[42] C. W. Tornøe, C. Christensen, M. Meldal, J. Org. Chem. 67 (2002) 3057-3064.

[43] V. V. Rostovtsev, L. G. Green, V. V. Fokin, K. B. Sharpless, Angew. Chem. Int. Ed. 41 (2002) 2596-2599.

[44] X. Yang, S. Wang, I. Ghiviriga, K. A. Abboud, A. S. Veige, Dalton Trans. 44 (2015) 11437-11443.

[45] A. R. Powers, I. Ghiviriga, K. A. Abboud, A. S. Veige, Dalton Trans. (2015), 10.1039/c5dt02405f.

[46] B. T. Worrell, J. A. Malik, V. V. Fokin, Science 340 (2013) 457-460.

[47] I. R. Whittall, M. G. Humphrey, S. Houbrechts, A. Persoons, D. C. R. Hockless, Organometallics 15 (1996) 5738-5745.

[48] W. Beck, Fehlhamm.Wp, P. Pollmann, H. Schachl, Chem. Ber. Recl. 102 (1969) 1976-1987.

[49] W. Beck, Fehlhamm.Wp, H. Bock, M. Bauder, Chem. Ber. Recl. 102 (1969) 3637-3646.

[50] L. Vaska, J. Peone, J. Chem. Soc. D (1971) 418-419.

[51] M. L. Gallego, A. Guijarro, O. Castillo, T. Parella, R. Mas-Balleste, F. Zamora, CrystEngComm 12 (2010) 2332-2334.

[52] A. R. Powers, X. Yang, T. J. Del Castillo, I. Ghiviriga, K. A. Abboud, A. S. Veige, Dalton Trans. 42 (2013) 14963-14966.

[53] A. L. Balch, V. J. Catalano, M. A. Chatfield, J. K. Nagle, M. M. Olmstead, P. E. Reedy, J. Am. Chem. Soc. 113 (1991) 1252-1258.

[54] A. L. Balch, V. J. Catalano, Inorg. Chem. 30 (1991) 1302-1308.

[55] A. L. Balch, V. J. Catalano, B. C. Noll, M. M. Olmstead, J. Am. Chem. Soc. 112 (1990) 7558-7566.

[56] A. L. Balch, V. J. Catalano, M. M. Olmstead, J. Am. Chem. Soc. 112 (1990) 2010-2011.

[57] A. L. Balch, B. J. Davis, M. M. Olmstead, Inorg. Chem. 28 (1989) 3148-3153.

[58] A. L. Casalnuovo, J. A. Casalnuovo, P. V. Nilsson, L. H. Pignolet, Inorg. Chem. 24 (1985) 25542559.

[59] A. L. Casalnuovo, T. Laska, P. V. Nilsson, J. Olofson, L. H. Pignolet, W. Bos, J. J. Bour, J. J. Steggerda, Inorg. Chem. 24 (1985) 182-187.

[60] A. L. Casalnuovo, T. Laska, P. V. Nilsson, J. Olofson, L. H. Pignolet, Inorg. Chem. 24 (1985) 233235.

[61] A. L. Casalnuovo, L. H. Pignolet, J. W. A. Vandervelden, J. J. Bour, J. J. Steggerda, J. Am. Chem. Soc. 105 (1983) 5957-5958.

[62] A. G. Sykes, K. R. Mann, J. Am. Chem. Soc. 112 (1990) 7247-7254.

[63] SHELXTL6.1, BRUKER-AXS, Madison, WI, 2008.

[64] O. V. Dolomanov, L. J. Bourhis, R. J. Gildea, J. A. K. Howard, H. Puschmann, J. Appl. Crystallogr. 42 (2009) 339-341. 